\title{
IL19 wt Allele
}

National Cancer Institute

\section{Source}

National Cancer Institute. IL19 wt Allele. NCI Thesaurus. Code C50926.

Human IL19 wild-type allele is located in the vicinity of $1 \mathrm{q} 32.2$ and is approximately $44 \mathrm{~kb}$ in length. This allele, which encodes interleukin-19 protein, plays a role in the signal transduction and in the activation of transcription 3 (STAT3). 